\title{
Dampness, Mold, and Health Conditions of Residents in Kampongs: A Case Study of Bandung, Indonesia
}

\author{
Kresna Bhayu Adinugraha \\ Graduate School for International \\ Development and Cooperation \\ Hiroshima University \\ Hiroshima, Japan \\ m183559@hiroshima-u.ac.jp \\ Tetsu Kubota \\ Graduate School for International \\ Development and Cooperation \\ Hiroshima University \\ Hiroshima, Japan \\ tetsu@ hiroshima-u.ac.jp
}

\author{
Junpei Sumi \\ Graduate School for International \\ Development and Cooperation \\ Hiroshima University \\ Hiroshima, Japan \\ m191621@hiroshima-u.ac.jp
}

Usep Surahman

Faculty of Technology and Vocational

Education

Indonesia University of Education

Bandung, Indonesia

u_surahman@yahoo.com

\author{
Cristiana de Almeida Parisi \\ Graduate School for International \\ Development and Cooperation \\ Hiroshima University \\ Hiroshima, Japan \\ cris.bahia.parisi@gmail.com
}

\begin{abstract}
The ultimate purpose of this study is to develop a new Kampong Improvement Program (KIP) in collaboration with the residents to improve their indoor environmental conditions, focusing especially on their indoor air quality (IAQ) and health of occupants. According to the WHO's report in 2013, acute respiratory infection $(16 \%)$ is the second top cause of death among infants under 5 years old after prematurity $(19 \%)$ in Indonesia [1]. The prevalence of respiratory diseases is suspected to be related to IAQ conditions in their houses. This paper presents the results of field investigations of dampness, mold and health conditions of residents in a typical Kampong area located in the city of Bandung, Indonesia. The result is later to be used as an example of how building physics and occupant's behavior may affect occupant's respiratory health.
\end{abstract}

Keywords: indoor air quality, respiratory diseases, dampness, mold, Kampong Improvement Program

\section{INTRODUCTION}

Despite the development trajectory towards formal, modernized, and vertical development of urban houses in Indonesia, the informal, sprawled and landed settlements known as 'Kampongs' are still thriving and not to be marginalized. The Kampong areas, while not necessarily fall under the 'slum' category, are still underdeveloped and unstandardized, comparing to the more formally developed settlements (i.e. apartments, flats, national housing). It is important to improve such areas to be at least the same standard in health and quality of life with what the current development intended.

Various Kampong Improvement Programs (KIPs) have been conducted both at the national and local level, and are continuously reinvented from the original KIP, which was conducted from the late 1970s. Currently, the KIP is initiated through a nationwide program, the so-called KOTAKU, and some of the local governments have their programs additionally for improving dwelling conditions via subsidies. Most programs give priority to uplifting the current slum settlements to informal but non-slum category.
However, the informal settlements such as Kampongs so far still have no standards in terms of indoor air quality (IAQ), which may affect their health conditions, particularly respiratory conditions among residents.

The present authors conducted an initial survey with 327 respondents in a typical Kampong area located in Bandung in 2018. The results indicated that $21.6 \%$ of the respondents showed some degrees of multiple chemical sensitivity, whereas $23.4 \%$ showed some degrees of symptoms of persistent cough, $13.4 \%$ on phlegm, $14.8 \%$ on asthma, and $24 \%$ on breathlessness. Further results of spirometry test on fewer samples also showed that $14.3 \%$ of the respondents have less than average total lung capacity (TLC) [2]. Actual observations found that dampness such as by water leakage frequently happens, and mold growth and mite problems are commonly seen. Furthermore, windows do not exist in many houses and exhaust fans are rarely installed even in the kitchens.

We conducted detailed field investigations in the selected five houses in the previously targeted Kampong area during dry and rainy seasons in 2018-19, respectively. This paper presents the results of the investigations, focusing especially on the dampness, mold and health conditions of residents.

\section{Methodology}

In Indonesia, a residential area is composed of several neighborhoods, which is called RW. One of the typical RWs was chosen in the city of Bandung for the investigation (Fig. 1). This RW was chosen mainly because the RW was willing to propose a new KIP program to the local authority to improve their living environments, and the RW was not covered by the other KIP programs such as KOTAKU. Other reasons are as follows: 1) it is a Kampong consisted of heterogeneously composed informal settlements, 2) it is not considered slum areas that receive common slum improvement programs from the government, 3) this neighborhood actively conducts community activities 
voluntary both independently or with the supports from private sectors (CSR) and academics (Bandung Institute of Technology) from which they won an award as the cleanest RW in Bandung in 2017, and 4) the environmental awareness of residents is relatively high.

After obtaining an informal consent from the head of RW and neighborhood association, the field measurements and interviews were conducted during the dry season (October 2018) and the rainy season (March 2019). The targeted subjects include 327 and 229 residents in dry and rainy seasons respectively for large-scale interviews, 34 houses for field measurement of air temperature and relative humidity (AT \& RH) and mold growth, and 5 houses for detailed field measurements of AT \& RH, mold growth, dust levels, and airflow rates. This paper focuses on the results of the detailed filed measurements for the selected five houses (see Fig. 1).

The 5 houses were selected to be measured in detail consisting of the following parameters:

1. Air temperature and relative humidity (AT \& RH) were measured at $1 \mathrm{~m}$ above the floor in several representative rooms ( $\mathrm{T} \& \mathrm{D} \mathrm{TR} 72 \mathrm{i})$. The data were recorded in every 5-minute interval.

2. Mold growth was predicted by using a fungal detector developed by Abe (1993). The fungal detectors were placed at $0.1 \mathrm{~m}$ above the floor in the same rooms as AT \& RH.

3. Dust levels: Suspended particle matter (SPM) and $\mathrm{PM}_{2.5}$ were measured in a 1-minute interval for about 2 days in the living room and bedroom respectively compared to the outdoors (Shibata LD5R).

4. Airflow rates of several representative rooms were measured through a tracer gas $\left(\mathrm{CO}_{2}\right)$ method under open/closed window conditions respectively.

In addition to the above field measurements, we also conducted building measurements and detailed observations including interviews.

\section{RESULTS AND DISCUSSION}

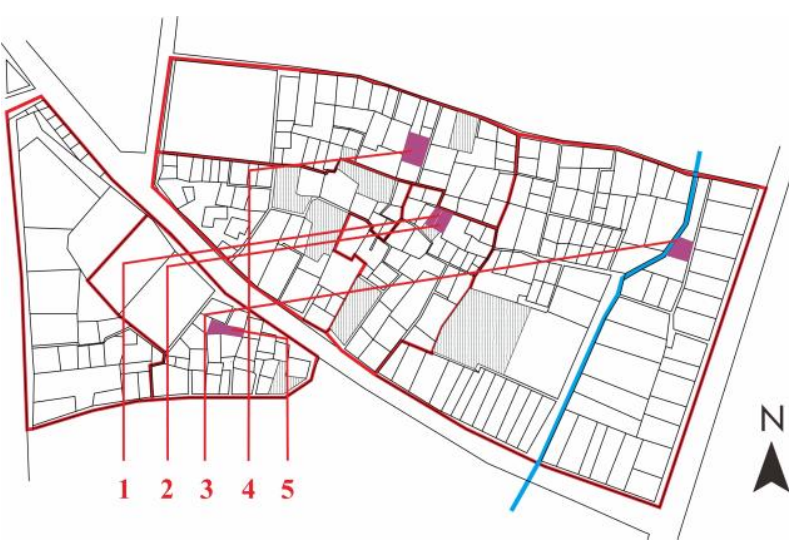

Fig. 1. Locations of Measured Units in the Target RW in Bandung

\section{A. Unit 1}

a. Overview

This house is one of the newest buildings in the Kampong (Table 1). Overall, it is well maintained with good air and thermal conditions. The house consists of three floors (3rd floor is a rooftop with a storage room), which is used as a drying place (Fig. 2). As shown, part of the floor is open for the room below with a glass roof on the top. This renders the second floor to be accessible directly to sunlight and therefore can be used for drying clothes as well. All rooms are painted with white color and therefore ensure a certain daylighting, especially on the $2^{\text {nd }}$ floor.

Some walls/floors are equipped with waterproof paint especially on the first floor to prevent water from permeating from the next house's bathroom. As shown in Fig. 2, AC is installed in the living room, whereas 3 exhaust fans are used to regulate air temperature and relative humidity. In addition, there are also 2 air purifiers that are moveable but usually placed near the kitchen and master bedroom.

TABLE I. GENERAL INFORMATION OF UNIT 1

\begin{tabular}{|c|c|c|c|}
\hline Building size & $40 \mathrm{~m}^{2} \times 3$ floors & Vehicle frequency & Rare \\
\hline Family member & 4 ( 2 adults, 2 children) & Vegetation & None \\
\hline Building age & 5 years & Pet & None \\
\hline Living duration & 5 years & House orientation & North \\
\hline \multirow{6}{*}{$\begin{array}{r}\text { Building material: } \\
\text { Floor } \\
\text { Wall } \\
\text { Door } \\
\text { Ceiling } \\
\text { Roof }\end{array}$} & \multirow{6}{*}{$\begin{array}{l}\text { Ceramic } \\
\text { Brick \& concrete } \\
\text { Wood } \\
\text { Cast } \\
\text { Clay tile }\end{array}$} & Income & 8-10 mil rupiahs \\
\hline & & Window opening: & \\
\hline & & Master bed & $13 / 24$ hours \\
\hline & & Living room & $0 / 24$ hours \\
\hline & & Smell & No \\
\hline & & Mite & No \\
\hline \multirow{5}{*}{$\begin{array}{r}\text { Finishing: } \\
\text { Floor } \\
\text { Wall } \\
\text { Door } \\
\text { Ceiling }\end{array}$} & \multirow{5}{*}{$\begin{array}{l}\text { Ceramic \& vinyl } \\
\text { Waterproof paint } \\
\text { Melamic paint } \\
\text { Waterproof paint }\end{array}$} & Water leaking & No \\
\hline & & Mold & Yes (kitchen, bathroom) \\
\hline & & $\mathrm{AC}$ & 1 (living room) \\
\hline & & Fan & 1 (movable) \\
\hline & & Exhaust fan & 3 (bed down, bathroom) \\
\hline Cleaning room & Every day & Active smoker & 0 \\
\hline Cleaning bathroom & Every week & Passive smoker & 0 \\
\hline \multirow[t]{2}{*}{ Drying laundry } & \multirow{2}{*}{$\begin{array}{l}\text { Indoor (drier) } \\
\text { Outdoor (sun-dried) }\end{array}$} & Scented product & $2 / 4$ member \\
\hline & & Fabric softener & 2/4 member \\
\hline Cleaning bed cloth & Every week & Gas stove & Yes \\
\hline Number of rooms & 9 (including storage) & Fabric softener & 2/4 member \\
\hline Number of furniture & 8 & Gas stove & Yes \\
\hline
\end{tabular}




\section{b. Dampness and mold}

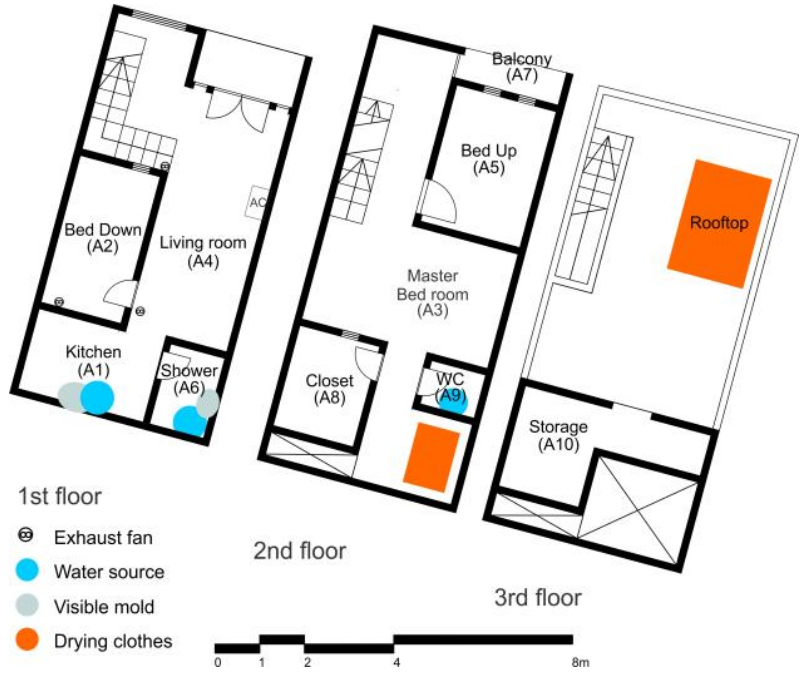

Fig. 2. Floor Plan of Unit 1

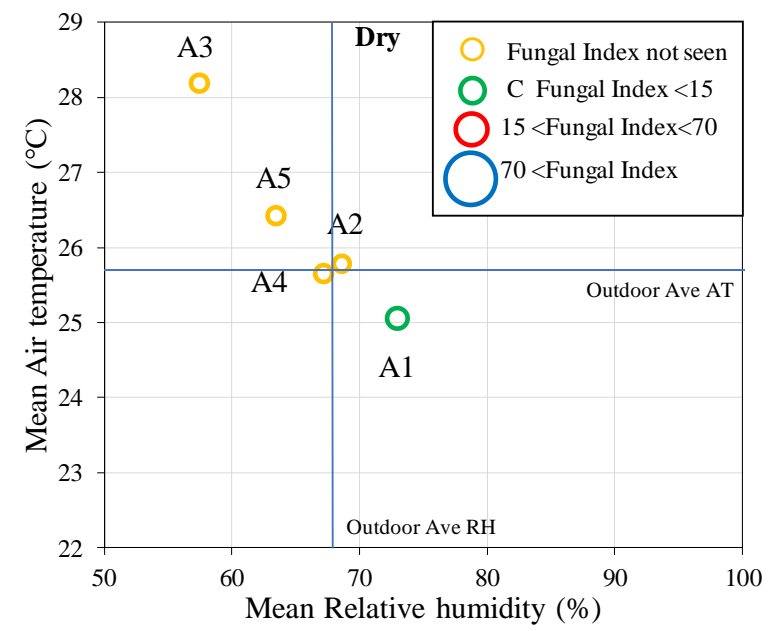

Fig. 3. Mold Results Related to AT \& RH in Unit 1 (The dry season)

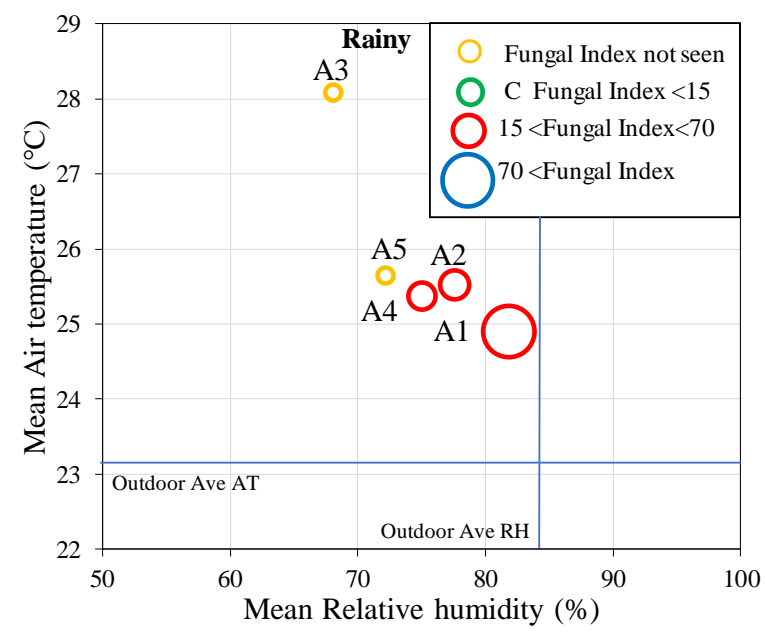

Fig. 4. Mold Results Related to AT \& RH in Unit 1 (Rainy Season)
Figs. 3-4 show the measured fungal indexes in relation with AT \& RH during dry and rainy season respectively. All AT \& RH were measured in each unit for 7 days in the dry season and 6 days in the rainy season. In each room of unit 1 , there are noticeable differences in average AT (higher in the dry season), and RH (higher in the rainy season) between the two seasons. Furthermore, temporal variations of AT \& RH differ depending on the floor levels. For example, higher AT and lower RH can be seen in the rooms on the $2^{\text {nd }}$ floor with a larger difference. This might be an indication that both rooms are influenced more by outdoor AT \& RH compared to the first floor. There are more openings both for airflow and sunlight on the $2^{\text {nd }}$ floor. In contrast, there is an $\mathrm{AC}$ on the $1^{\text {st }}$ floor, and therefore windows tend to be closed more.

As shown in Fig. 4, fungal index (FI) is increased up to 60.7 (A1), showing a high possibility of propagation. High FI results can be seen especially when the $\mathrm{RH}$ is higher than $70 \%$ in both seasons (Figs. 3-4). According to the observation, visible mold was only found at the kitchen and shower downstairs, with higher levels of FI at the kitchen (A1), especially in the rainy season. This leads to the implication that mold was caused mostly by internal sources of vapor and humidity by cooking and showering, not by damages in the building materials (i.e. floor, roof) or water leaks. It should be observed that, although the FI is also high in the living room (19.4) and bedroom (21.2) on the first floor during the rainy season, there is no visible mold. This could be due to the fact that the first floor is equipped with an $\mathrm{AC}$, which helps keeping humidity level low and three exhaust fans which can help to keep the room ventilated.

Besides the kitchen, the other two measured rooms on the ground floor (A2 and $\mathrm{A} 4$ ) recorded the highest $\mathrm{RH}$ during the rainy season (Fig. 4). Although the RH was almost as high as at the kitchen $(70-80 \%)$, the FI value for these rooms was not as high as that of the kitchen. This can be related to the fact that the kitchen has poorer ventilation compared to the other rooms on the first floor, in addition to the moisture generation as discussed before.

\section{c. $\quad S P M$ and $P M_{2.5}$}

Indoor dust levels are comparably lower than the outdoors, indicating that dust source is likely dominated by outdoor sources (Figs. 5-6). The outdoor SPM values range from $19-277 \mu \mathrm{g} / \mathrm{m}^{3}$, while the corresponding indoor values are $0-66 \mu \mathrm{g} / \mathrm{m}^{3}$ during the dry season. Meanwhile, the outdoor $\mathrm{PM}_{2.5}$ values range from 9-172 $\mu \mathrm{g} / \mathrm{m}^{3}$, while the corresponding indoor values are $10-96 \mu \mathrm{g} / \mathrm{m}^{3}$ during the dry season. The indoor dust levels are increased during the rainy season, ranging from $18-333 \mu \mathrm{g} / \mathrm{m}^{3}$ in SPM and $0-1556 \mu \mathrm{g} / \mathrm{m}^{3}$ in $\mathrm{PM}_{2.5}$, respectively. Red lines in the graphs indicate the acceptable levels of dust particles by the WHO [3] and the Indonesian government [4].

\section{d. Recommendations}

Unit 1 has quite stable AT \& RH conditions mainly because AC is usually used with closing windows, especially in the living room. Indoor AT is higher while RH is lower than the outdoors in the dry season in the master bedroom (A3). This might be caused by the fact that A3 is closely 


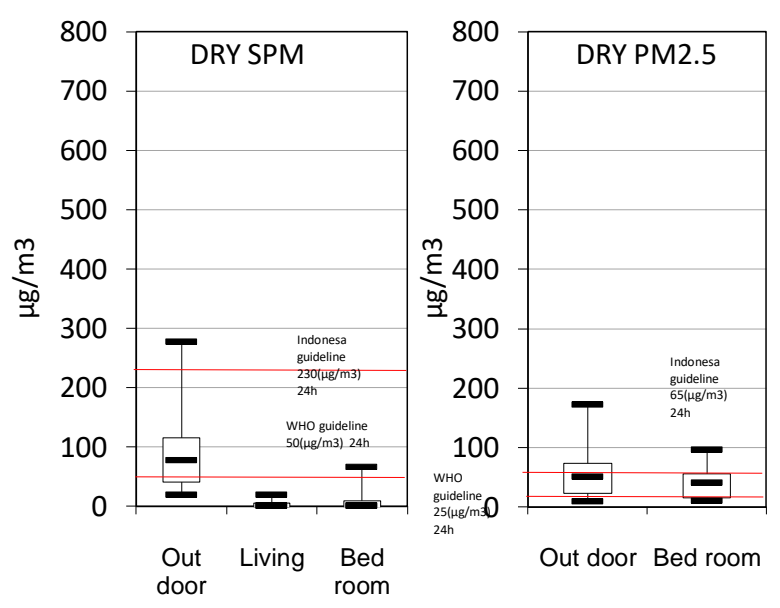

Fig. 5. Unit 1 Dust Measurement Results (Dry Season)
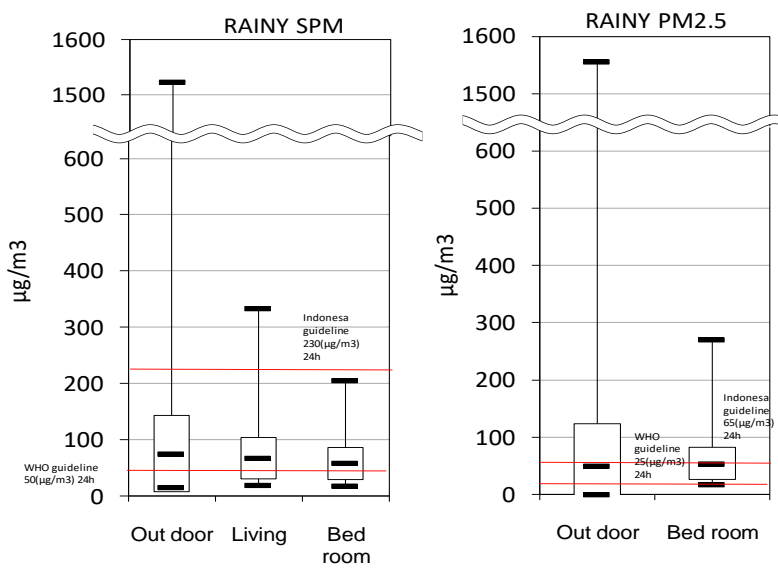

Fig. 6. Unit 1 Dust Measurement Results (Rainy Season)

connected to the large sunroof and stairs leading to the roof and therefore largely affected by the outdoor conditions.

Since no windows can be open at the backside of the building due to the existence of chicken coop, the best ventilation option would be to substitute the glass roof by a skylight window that could be opened a few hours a day, especially at times when someone is cooking or taking a shower. In addition, it would be recommended to install a fan at the shower and the kitchen to stimulate the airflow whenever the weather doesn't permit the opening of windows and turn them on any time there is the possibility of moisture collection.

Additionally, these environments where mold is already visible should be cleaned and painted with anti-mold paint, which protects walls and ceilings in humid environments.

\section{B. Unit 2 \\ a. Overview}

This house is one of the old buildings in the Kampong (37 years). It is a simple one-story house with 3 bedrooms (Table 2). All the openings are located on the front side of the house (Fig. 7). Both the right and left sides are bordered with the next houses, causing them to have no openings in most rooms. Originally, there was a ventilation opening in the kitchen (B5), but the occupants sealed it off to avoid the smell from the chicken coop just behind the building. The living room (B2) has windows that never be opened, while the front bedroom (B3) has windows which are opened during the day. No air conditioning or fans exist. There is an instance of water permeating in the wall between the bathroom and kitchen (Fig. 7). This rendered the house to be quite damp and humid. The surveyor's first impression of the house is that it rather lacks maintenance, slightly low in temperature, high humidity and dampness, and lack of natural lighting. This house received a subsidy from local government in late November 2018 and has been improved especially around the kitchen and storage room (Fig. 7).

\section{b. Dampness and mold}

A brief renovation was conducted between dry and rainy season measurement periods by using a subsidy from the Bandung City government. The roof structure for the kitchen and storage area were replaced by new roofs with sunroof, new flooring, waterproofing of the wall, and significant clean-ups. This caused a dramatic change in the back rooms and its adjacent rooms of the building. The walls are no longer permeated by water and more sunlight enters the rooms. Due to the renovation, humidity conditions in the kitchen (B5) was slightly improved as shown in Fig. 9.
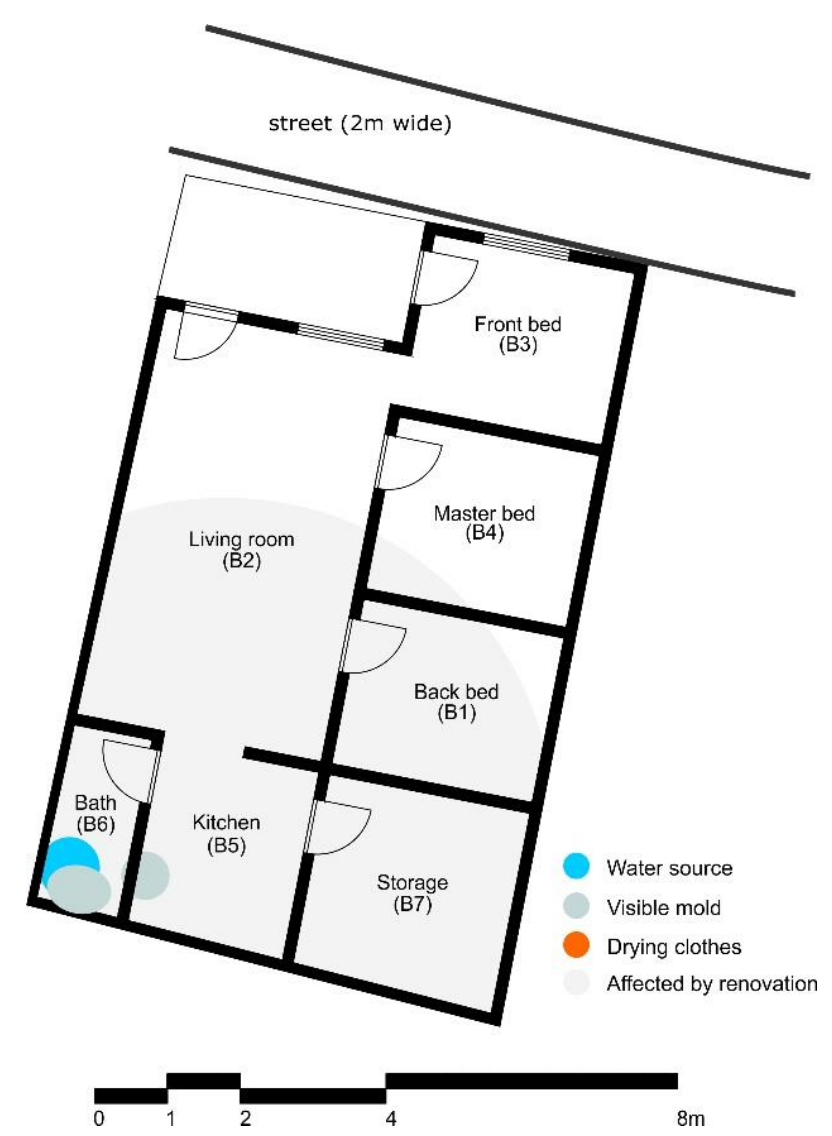

Fig. 7. Floor Plan of Unit 2 
TABLE II. GENERAL INFORMATION OF UNIT 2

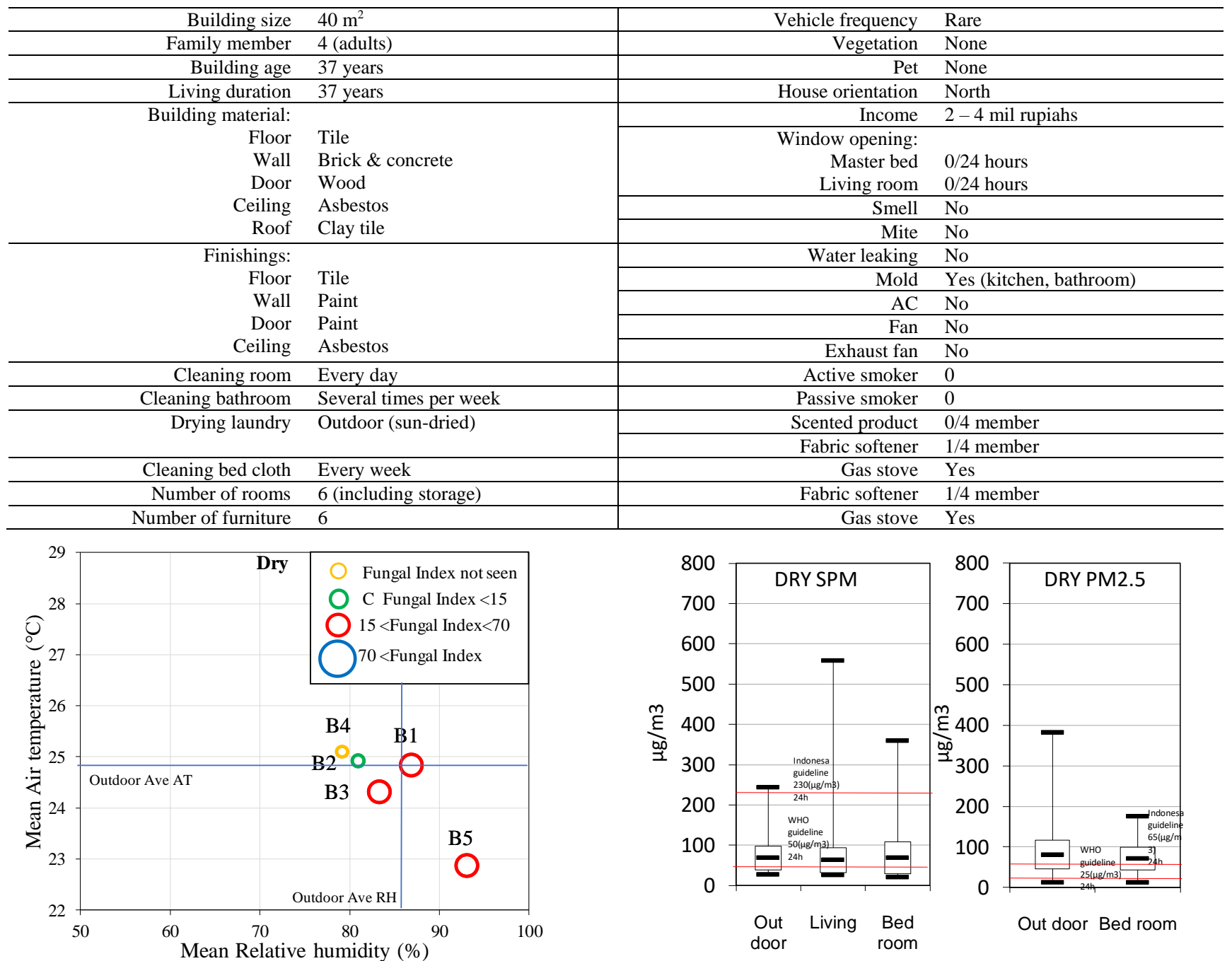

Fig. 8. Mold Results Related to AT \& RH in Unit 2 (Dry Season)

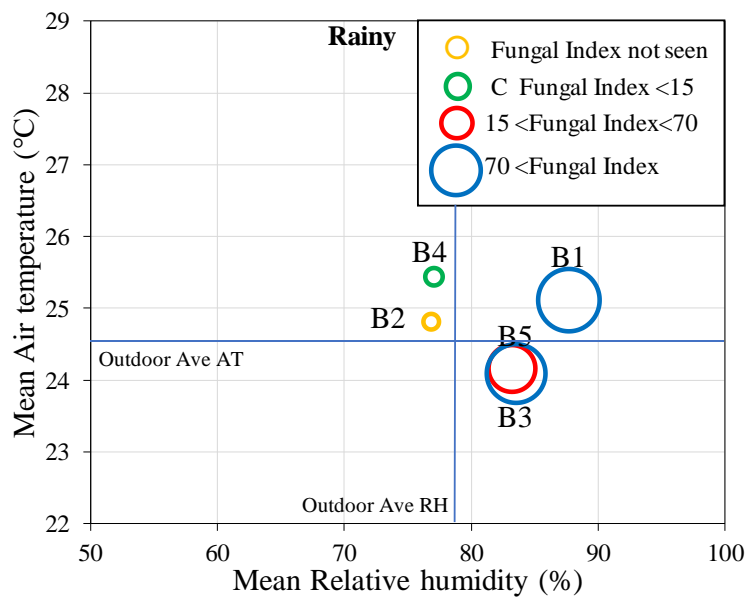

Fig. 9. Mold Results Related to AT \& RH in Unit 2 (Rainy Season)

According to the observation, visible mold was only found at the kitchen and shower, but the FI levels were very high for both dry and rainy season not only in the kitchen (B5) but also in the front bedroom (B3) and the back bedroom (B1). It should be noted that, during the rainy season, the FI in the front and back bedrooms was even higher than that in
Fig. 10. Unit 2 Dust Measurement Results (Dry Season).
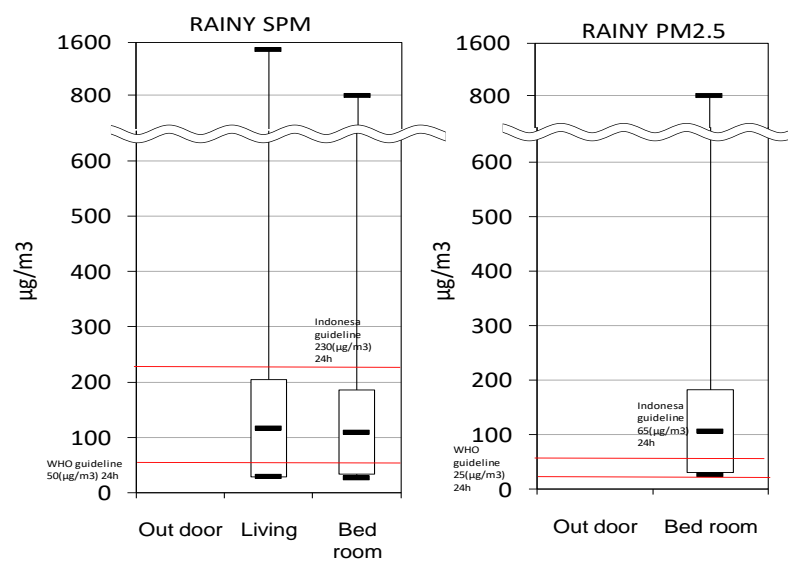

Fig. 11. Unit 2 Dust Measurement Results (Rainy Season).

the kitchen (Fig. 9). This leads to the implication that mold was caused by internal sources of vapor and humidity not only by cooking and showering, just like in Unit 1, but also by other sources that could include water leaks (from pipes, roofs or walls, taps or showers), darkness, poor ventilation and water at the house's foundation. 
c. $\quad S P M$ and $P M_{2.5}$

As shown in Figs. 10-11, in Unit 2, indoor dust levels (both SPM and $\mathrm{PM}_{2.5}$ ) are found to be equal or even higher than the outdoors. This is mainly because windows and openings are closed or absent in both rooms. Since Units 1 and 2 are close to each other, outdoor dust levels are noticeably similar. Hence, relatively high indoor dust levels in Unit 2 are mainly caused by indoor sources.

\section{d. Recommendations}

The main problem with Unit 2 is caused by water leaking and the lack of opening/ventilation. After removing the water leaking by the renovation, the humidity levels in some rooms such as the kitchen (B5) reduced despite the rainy season. This renovation can be applied to other rooms in the future. Other than that, it is obvious that Unit 2 needs more ventilation and increasing window opening behavior in the available rooms (B2). No windows can be open at the backside of the building due to the existing chicken coop, so the best ventilation option would be to change the roof, creating a higher more open design with skylight windows that could be opened a few hours a day, bringing outside air and sunlight in. In addition, it would be recommended to install a fan at least at the shower and the kitchen to stimulate the airflow and turn them on any time there is the possibility of moisture collection.

Additionally, these environments where mold is already visible should be cleaned and painted with anti-mold paint, which protects walls and ceilings in humid environments. The existing furniture should also be checked for the presence of mold.

\section{Unit 3}

a. Overview

This house was constructed about 15 years ago (Table 2). It is located exactly by the river, about 2-3 $\mathrm{m}$ above the water level (Fig. 12). In general, most of the ventilation and daylighting come from the west side of the building (north and south are bordered with next houses, while the east side is only separated by one-meter alley from the next house (Fig. 12). Motorbikes sometimes pass through this alley, rendering the cramped space to be quite polluted. Though the west/riverside is more aerated and lighted, this side is particularly humid, most likely due to river water and bathroom. Surveyor's impression on this house is that the air quality/thermal condition is averagely pleasant, rather humid but still satisfactory, and without much damp sensation compared to other units, especially on the 2 nd floor.
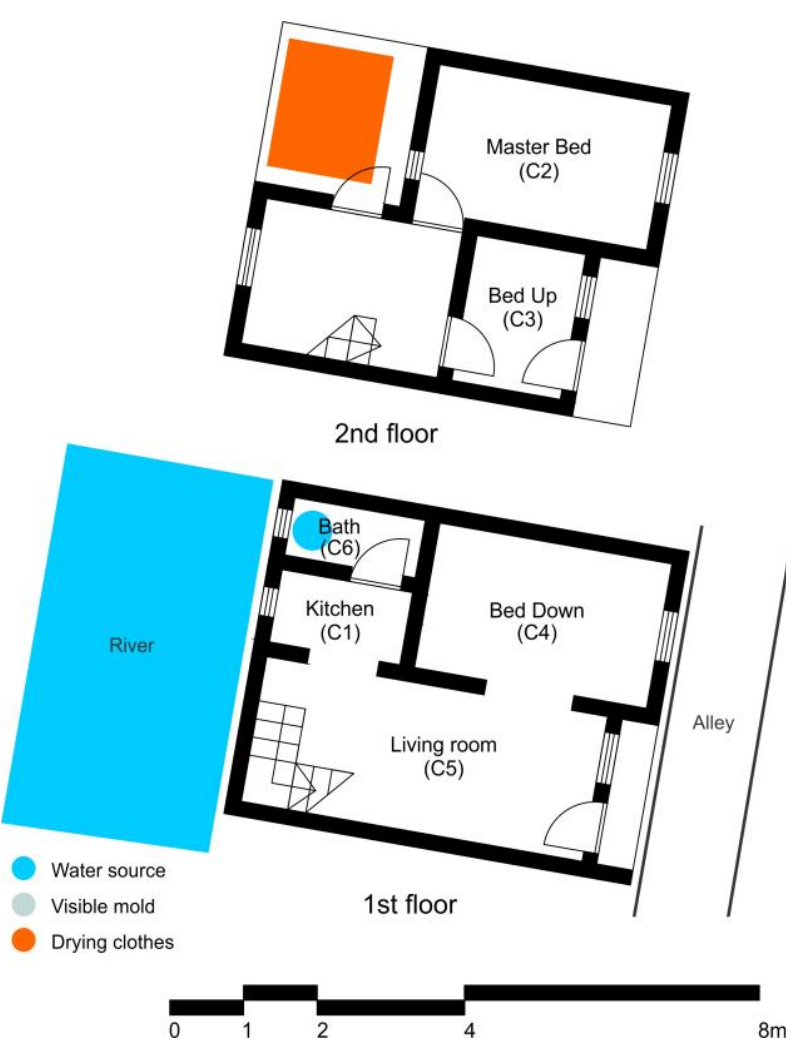

Fig. 12. Floor Plan of Unit 3

TABLE III. GENERAL INFORMATION OF UNIT 3

\begin{tabular}{|c|c|c|c|}
\hline Building size & $44 \mathrm{~m}^{2}$ & Vehicle frequency & Rarely \\
\hline Family member & 3 (adults) & Vegetation & Minimum (river bank) \\
\hline Building age & 15 years & Pets & None \\
\hline Living duration & 15 years & House orientation & East \\
\hline \multirow{6}{*}{$\begin{array}{r}\text { Building material: } \\
\text { Floor } \\
\text { Wall } \\
\text { Door } \\
\text { Ceiling } \\
\text { Roof }\end{array}$} & \multirow{6}{*}{$\begin{array}{l}\text { Ceramic } \\
\text { Brick \& concrete } \\
\text { Wood } \\
\text { Concrete \& plywood } \\
\text { Clay tile }\end{array}$} & Income & - \\
\hline & & Window opening: & \\
\hline & & Master bed & $12 / 24$ \\
\hline & & Living room & $0 / 24$ \\
\hline & & Smell & No \\
\hline & & Mite & No \\
\hline \multirow{5}{*}{$\begin{array}{r}\text { Finishings: } \\
\text { Floor } \\
\text { Wall } \\
\text { Door } \\
\text { Ceiling }\end{array}$} & \multirow{5}{*}{$\begin{array}{l}\text { Ceramic } \\
\text { Paint } \\
\text { Paint } \\
\text { Paint \& plywood }\end{array}$} & Water leaking & No \\
\hline & & Mold & Yes (bathroom) \\
\hline & & $\mathrm{AC}$ & No \\
\hline & & Fan & 1 (bed up) \\
\hline & & Exhaust fan & No \\
\hline Cleaning room & Every day & Active smoker & 0 \\
\hline Cleaning bathroom & Every week & Passive smoker & 0 \\
\hline \multirow[t]{2}{*}{ Drying laundry } & \multirow[t]{2}{*}{ Outdoor (sun-dried) } & Scented product & $3 / 3$ member \\
\hline & & Fabric softener & $3 / 3$ member \\
\hline Cleaning bed cloth & - & Gas stove & Yes \\
\hline Number of rooms & 7 & Fabric softener & $3 / 3$ member \\
\hline Number of furniture & 5 & Gas stove & Yes \\
\hline
\end{tabular}




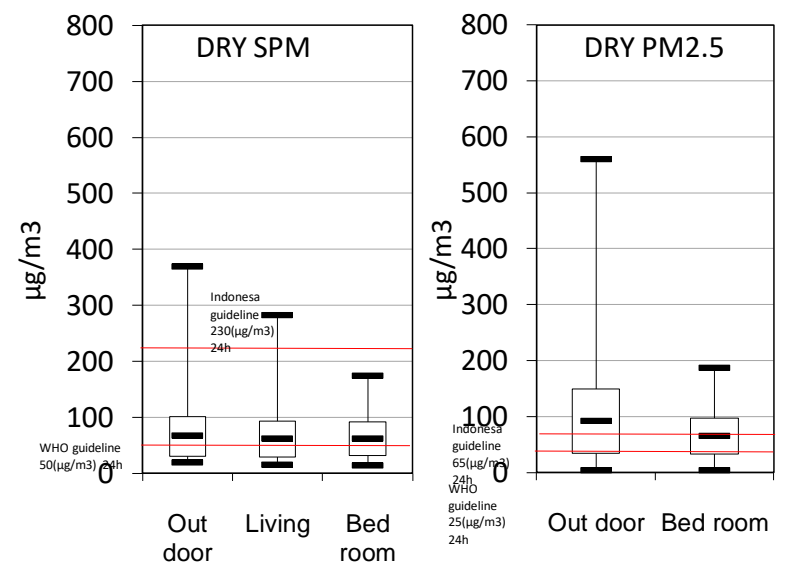

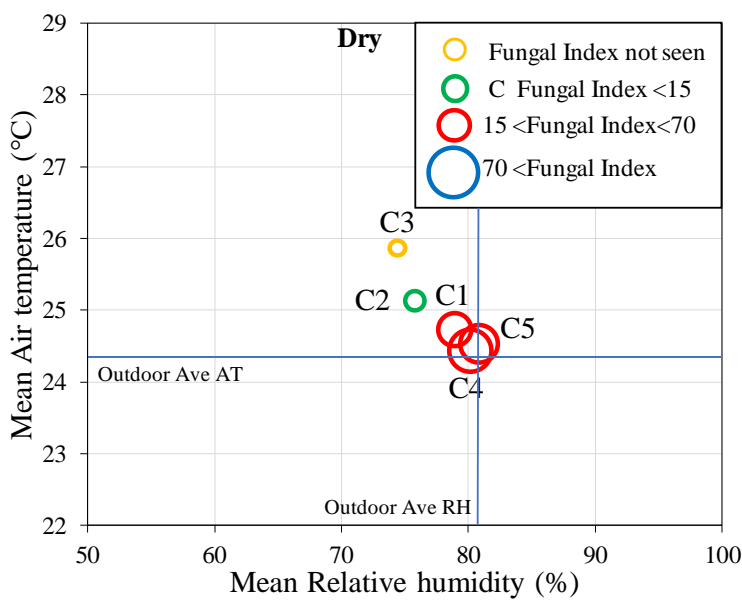

Fig. 13. Mold Results Related to AT \& RH in Unit 3 (Dry Season)

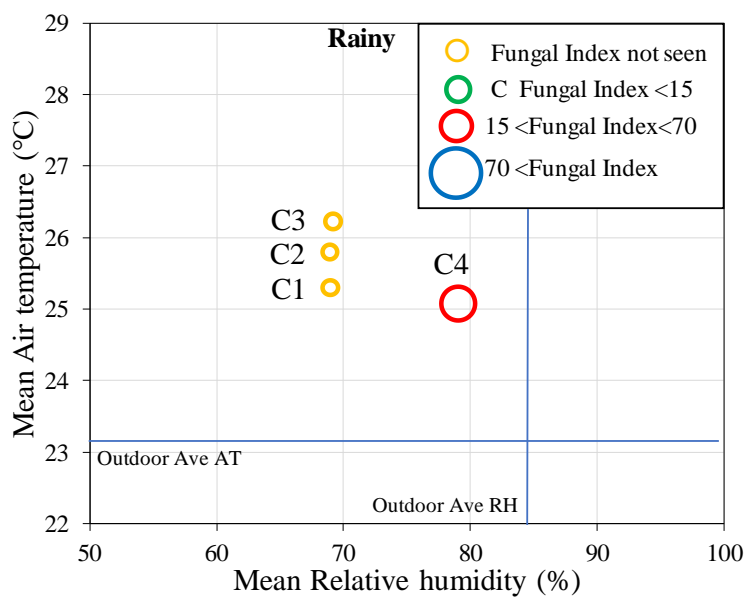

Fig. 14. Mold Results Related to AT \& RH in Unit 3 (Rainy Season)

\section{b. Dampness and mold}

Overall, the average AT in Unit 3 is relatively higher in the rainy season while higher RH is seen in the dry season (Figs. 13-14). Between the two measurements, there was no physical change in the building. Accordingly, FI shows higher values in the dry season than in the rainy season. This might be because of the behavioral change by the occupants.

According to the observation, visible mold was only found at the bathroom (only water source of the house) and, in addition, the levels of the FI were very high for both dry and rainy season at the bedroom (C4). FI values were high only on the first floor of the house. This can be related to the fact that there is a river running behind the building.

It is mentioned in the questionnaire that the windows in the living room are never opened, which can also compromise the air circulation on the first floor and increase humidity.

\section{c. $\quad S P M$ and $P M_{2.5}$}

As shown in Figs. 15-16, outdoor dust levels in Unit 3, particularly $\mathrm{PM}_{2.5}$, are mostly higher than those in indoor, indicating that dust particles mainly come from outside, though the outdoor levels are not as high as those near Units 1 and 2 (Figs. 15-16).
Fig. 15. Dust Measurement Results in Unit 3 (Dry Season)
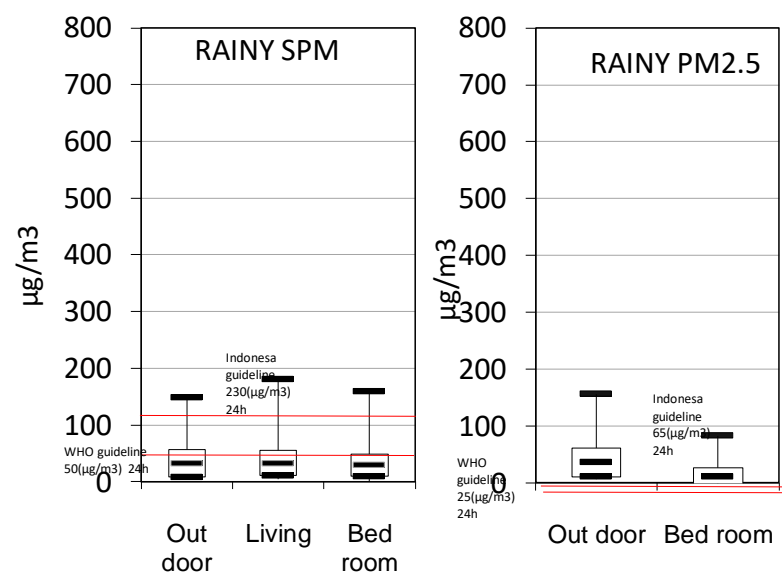

Fig. 16. Dust Measurement Results in Unit 3 (Rainy Season)

\section{d. Recommendations}

It is recommended to install exhaust fans on the westward side of the house especially on the first floor to create cross ventilation. Higher average SPM level in the living room at the rainy season may be caused by cooking activities as there is no pet nor active smokers in the house. To reduce the effect, opening windows or adding exhaust fans around the kitchen is also recommended especially during the cooking period.

Since cross-ventilation is existing on the second floor of Unit 3 (Fig. 12), the issue appears to be only on the first floor, as the FI values for the living room (32.2) and bedroom (38.7) are considerably high. Therefore, it is recommended to increase the ventilation on this floor, and this can be achieved by opening a window at the back (river) side of the living room, allowing better cross-ventilation.

The apparent mold at the bathroom probably has its source of the vapor from the shower and the presence of constant moisture in this room. Consequently, it would be advised to install an exhaust fan there. There doesn't seem to be any problem with the roof and the foundation of the house, but special attention should be paid to the existing river and how it can be related to the RH values of this house. 
TABLE IV. GENERAL INFORMATION OF UNIT 4

\begin{tabular}{|c|c|c|c|}
\hline Building size & $150 \mathrm{~m}^{2}$ & Vehicle frequency & None \\
\hline Family member & 2 (adults) & Vegetation & High (garden) \\
\hline Building age & 37 years & Pet & Cats $(>5)$ \\
\hline Living duration & 18 years & House orientation & East \\
\hline \multirow{6}{*}{$\begin{array}{r}\text { Building material: } \\
\text { Floor } \\
\text { Wall } \\
\text { Door } \\
\text { Ceiling } \\
\text { Roof }\end{array}$} & \multirow{6}{*}{$\begin{array}{l}\text { Tile } \\
\text { Brick \& concrete } \\
\text { Wood } \\
\text { Concrete } \\
\text { Clay tile }\end{array}$} & Income & $14-16$ million rupiahs \\
\hline & & Window opening: & \\
\hline & & Master bed & $0 / 24$ \\
\hline & & Living room & $0 / 24$ \\
\hline & & Smell & Yes (dust - bedrooms) \\
\hline & & Mite & No \\
\hline \multirow{5}{*}{$\begin{array}{r}\text { Finishings: } \\
\text { Floor } \\
\text { Wall } \\
\text { Door } \\
\text { Ceiling }\end{array}$} & \multirow{5}{*}{$\begin{array}{l}\text { Tile \& rug } \\
\text { Paint } \\
\text { Paint } \\
\text { Plywood \& paint }\end{array}$} & Water leaking & No \\
\hline & & Mold & No \\
\hline & & $\mathrm{AC}$ & No \\
\hline & & Fan & No \\
\hline & & Exhaust fan & No \\
\hline Cleaning room & Several times per week & Active smoker & 1 \\
\hline Cleaning bathroom & Several times per week & Passive smoker & 0 \\
\hline \multirow[t]{2}{*}{ Drying laundry } & \multirow{2}{*}{$\begin{array}{l}\text { Outdoor (sun-dried) } \\
\text { Drier }\end{array}$} & Scented product & $2 / 2$ member \\
\hline & & Fabric softener & $2 / 2$ member \\
\hline Cleaning bed cloth & Every day & Gas stove & Yes \\
\hline Number of rooms & 8 & Fabric softener & $2 / 2$ member \\
\hline Number of furniture & 7 & Gas stove & Yes \\
\hline
\end{tabular}

\section{Unit 4}

\section{a. Overview}

This house is one of the old houses in the Kampong (Table 4). It was established by the previous head of the family who was a respected university teacher for his big family. Currently, the house is inhabited only by one of his daughters and her only son. All functional windows/door openings are facing east, while other openings on the other sides are blocked by the next house completely. There is a wellvegetated garden with a fish pond (Fig. 17). A notable difference from other units is the existence of cats $(>5)$ in the house which sheds fur and sometimes even urinates around the house. Surveyor's first impression was a pleasantly cool temperature, rather humid condition, the quite recognizable smell of pets, and damp sensation in most of the rooms.

\section{b. Dampness and mold}

Unit 4 has few openings which rarely open according to the occupants. As a result, most of the rooms record relatively high average RH, rendering high FI values in both seasons (Figs. 18-19). This is partially due to the existence of pond and garden in front side of the house where all the openings are located, whereas window opening behavior and cleaning behavior may be some of the possible factors for the increased $\mathrm{RH}$ among others.

According to the available information, there was no visible mold in this unit. Nevertheless, the levels of the FI were considerably high for both dry and rainy season in all the measured rooms, especially at the living room (D5), right bedroom (D1) and master bedroom (D2). As only the east side of the house is not blocked, it is almost impossible to have cross-ventilation in this unit. This condition is further worsened by the fact that a part of the house is completely closed due to the presence of cats.

\section{c. $\quad S P M$ and $P M_{2.5}$}

As shown in Figs. 20-21, both SPM and $\mathrm{PM}_{2.5}$ are significantly higher than the outdoors. For example, outdoor SPM ranged from $0-363 \mu \mathrm{g} / \mathrm{m}^{3}$, whereas the corresponding

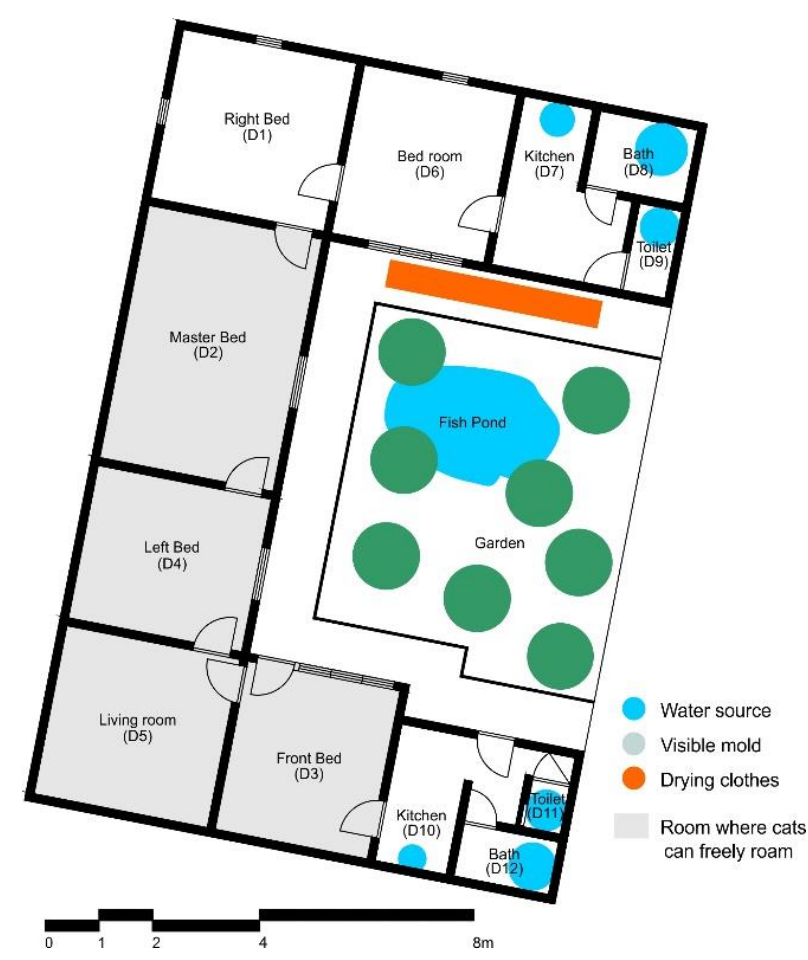

Fig. 17. Floor plan of Unit 4

indoor levels ranged from 33-783 $\mu \mathrm{g} / \mathrm{m}^{3}$ during the dry season. The results indicate that the dust sources are most likely present inside, especially in the master bedroom (Fig. 20).

\section{d. Recommendations}

Referring to the floor plan, this unit is almost completely closed except for the front side of the house. Even so, the available windows seem to never be opened. The humidity levels are, therefore, relatively higher than those in other units. The water vapor coming from the pond and garden might increase the indoor humidity levels as well. To lighten 

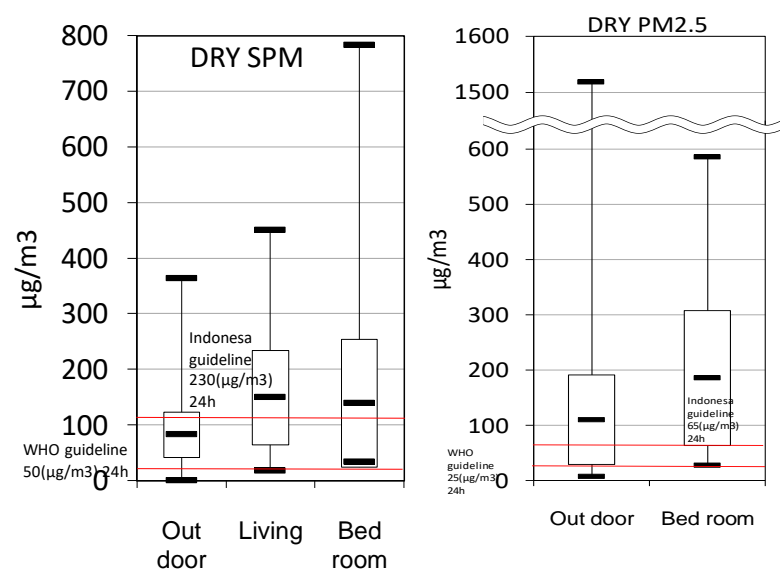

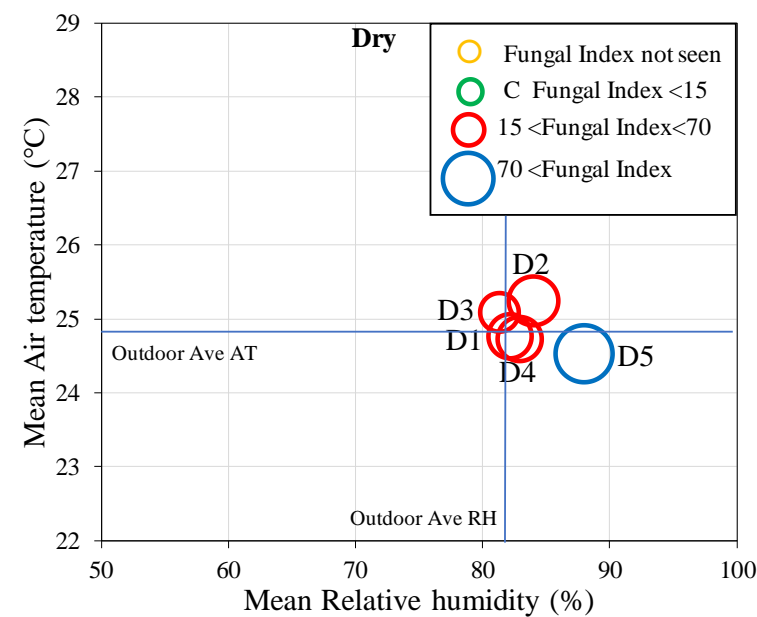

Fig. 18. Mold Results Related to AT \& RH in Unit 4 (Dry Season)

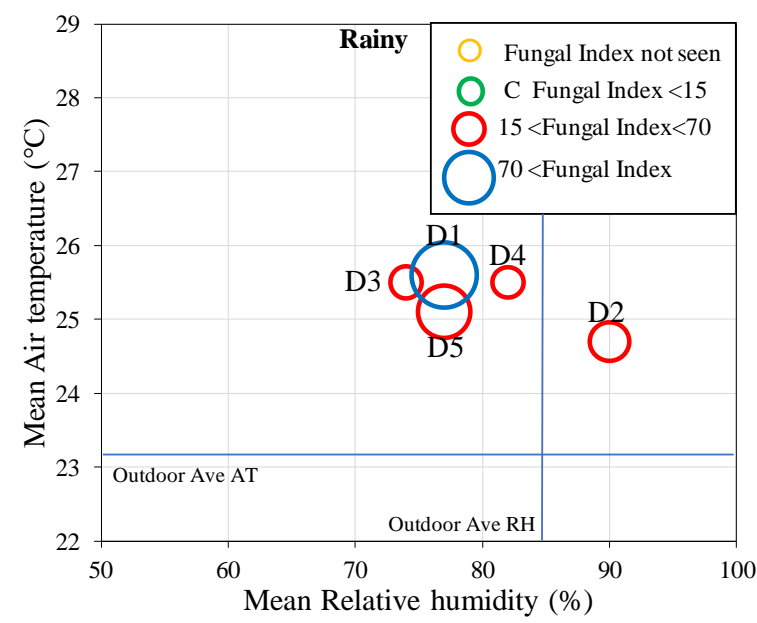

Fig. 19. Mold Results Related to AT \& RH in Unit 4 (Rainy Season)

this problem, at least outward exhaust fans should be installed on the open side of the house, including the east side.

As mentioned before, most of the dust particles in Unit 4 originate from indoor activities. Smoking behavior, less frequent cleaning behavior, and the existence of pets might be the main cause of it.

It is recommended to increase the ventilation and the opening of the windows. A net can be installed at the windows of the rooms where cats roam freely, to that the window can be opened and the cats won't escape. The installation of extractor fans and vents in the walls could be also a helpful solution, especially the second as it is a cheap but effective solution.

\section{E. Unit 5}

a. Overview

Unit 5 is one of the old buildings in the Kampong (Table 5). The occupants consist of a father and his 3 sons. All except the youngest are active smokers. Since this house doesn't have any garage, 3 motorbikes are always parked in the living room. All the bedrooms are not well ventilated, but the small windows are always opened to the back corridor connecting to the kitchen. Most of the other openings are located on the front side of the house, but they are rarely opened. For
Fig. 20. Dust Measurement Results in Unit 4 (Dry Season)

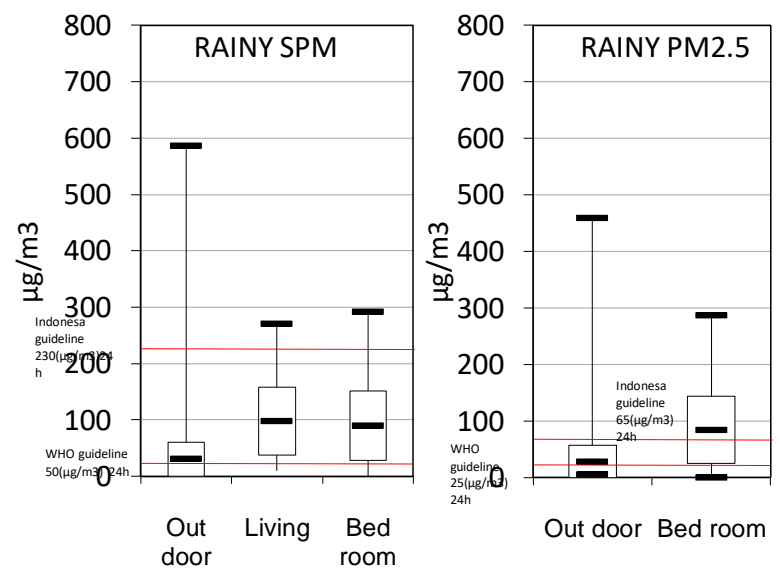

Fig. 21. Dust Measurement Results in Unit 4 (Rainy Season)

laundry, this household dries the clothes on the rooftop, which can be accessed with a stair from a room bordering the front bed (Fig. 22). Around 4 pet cats also live in this house. This unit also has an indoor footwear policy, which means that indoor floors tend to be dusty. Surveyor's impression on this unit is that the air condition is quite damp, humid, pleasant air temperature, and slightly unmaintained conditions in most of the rooms.

\section{b. Dampness and mold}

Most rooms in this unit show averaged AT \& RH conditions among the units surveyed (Figs. 23-24). According to the available information, mold was visible in the kitchen and the bathroom. The FI values are not extremely high for any of the rooms and the highest values were recorded at the kitchen (E3) and right bedroom (E4) (Fig. 23). There is not much ventilation at this unit, as the windows are only located at the front of the house and are kept closed most of the time (Fig. 22).

\section{c. $S P M$ and $P M_{2.5}$}

As shown in Figs. 25-26, dust level profiles in Unit 5 are similar to those of Unit 4 . Although air change rates are better in this unit, more active smokers are present, and therefore indoor dust sources are prominently high. Furthermore, the outdoor dust levels are also severe in this unit mainly because 
TABLE V. GENERAL INFORMATION OF UNIT 5

\begin{tabular}{|c|c|c|c|}
\hline Building size & $46 \mathrm{~m}^{2}$ (2 floors) & Vehicle frequency & Frequent \\
\hline Family member & 4 (adults) & Vegetation & None \\
\hline Building age & 42 years & Pet & Cats (4) \\
\hline Living duration & 42 years & House Orientation & North \\
\hline \multirow{6}{*}{$\begin{array}{r}\text { Building material: } \\
\text { Floor } \\
\text { Wall } \\
\text { Door } \\
\text { Ceiling } \\
\text { Roof }\end{array}$} & \multirow{6}{*}{$\begin{array}{l}\text { Tile } \\
\text { Brick \& concrete } \\
\text { Wood } \\
\text { Asbestos } \\
\text { Clay tile }\end{array}$} & Income & $2-4$ mil rupiahs \\
\hline & & Window opening: & \\
\hline & & Master bed & $0 / 24$ hours \\
\hline & & Living room & $0 / 24$ hours \\
\hline & & Smell & No \\
\hline & & Mite & No \\
\hline \multirow{5}{*}{$\begin{array}{r}\text { Finishings: } \\
\text { Floor } \\
\text { Wall } \\
\text { Door } \\
\text { Ceiling }\end{array}$} & \multirow{5}{*}{$\begin{array}{l}\text { Tile, concrete } \\
\text { Paint } \\
\text { Paint } \\
\text { Paint }\end{array}$} & Water leaking & No \\
\hline & & Mold & Yes (kitchen, bathroom) \\
\hline & & $\mathrm{AC}$ & None \\
\hline & & Fan & None \\
\hline & & Exhaust fan & None \\
\hline Cleaning room & Several times per week & Active smoker & 3 \\
\hline Cleaning bathroom & Several times per week & Passive smoker & 1 \\
\hline \multirow[t]{2}{*}{ Drying laundry } & \multirow[t]{2}{*}{ Rooftop (sun-dried) } & Scented product & $2 / 4$ member \\
\hline & & Fabric softener & $3 / 4$ member \\
\hline Cleaning bed cloth & Every month & Gas stove & Yes \\
\hline Number of rooms & 8 (including storage) & Fabric softener & $3 / 4$ member \\
\hline Number of furniture & 3 & Gas stove & Yes \\
\hline
\end{tabular}

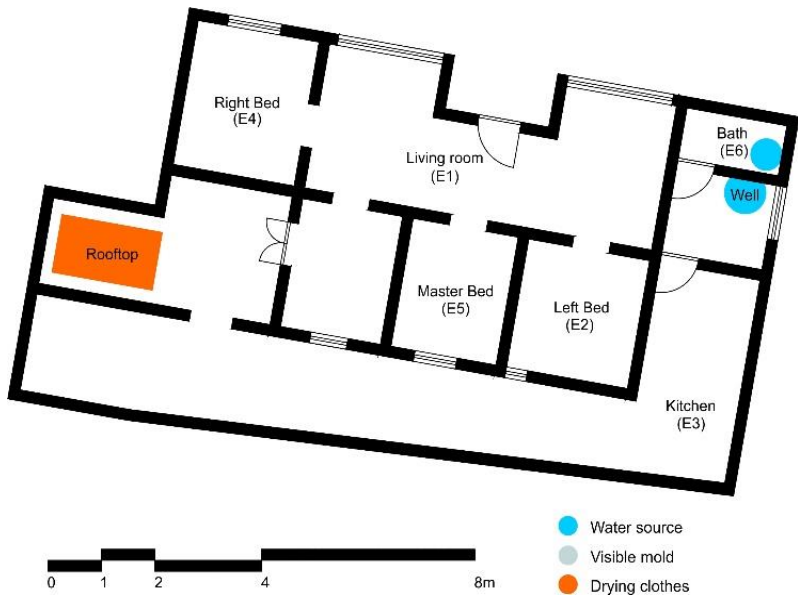

Fig. 22. Floor plan of Unit 5

the house is situated next to the main road (Fig. 1). Most of the indoor dust levels are above the recommended guidelines, especially in the bedroom (Figs. 25-26).

\section{d. Recommendations}

The biggest problem with this unit is also the absence of cross-ventilation. The recommendations for this unit can be the same as the previous unit, which means it is recommended to increase the ventilation and the opening of the windows.

The installation of extractor fans and vents in the walls could be also a helpful solution, especially the second as it is a cheap but effective solution. As there is only one floor, it is also possible to install skylight windows that could be opened a few hours a day, bringing outside air and sunlight in. In addition, it would be recommended to install a fan at least at the shower and the kitchen to stimulate the airflow and turn them on any time there is the possibility of moisture collection.

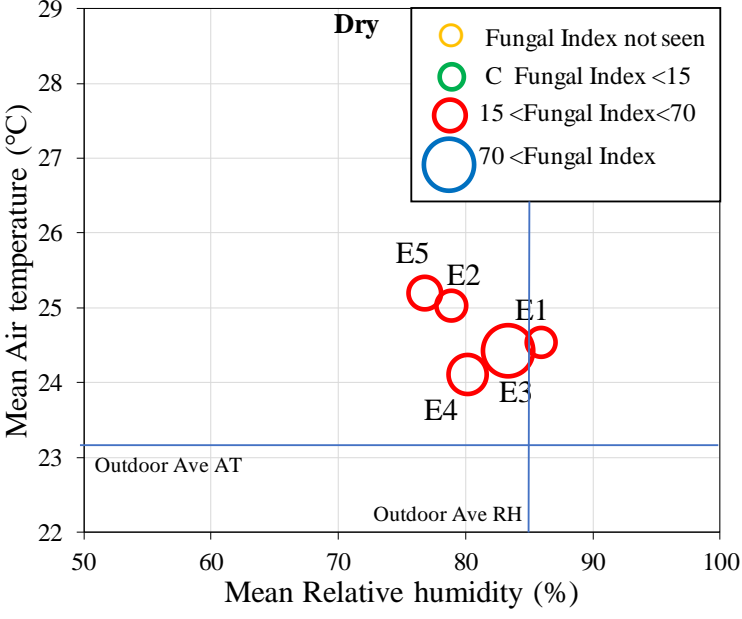

Fig. 23. Mold Results Related to AT \& RH in Unit 5 (Dry Season)

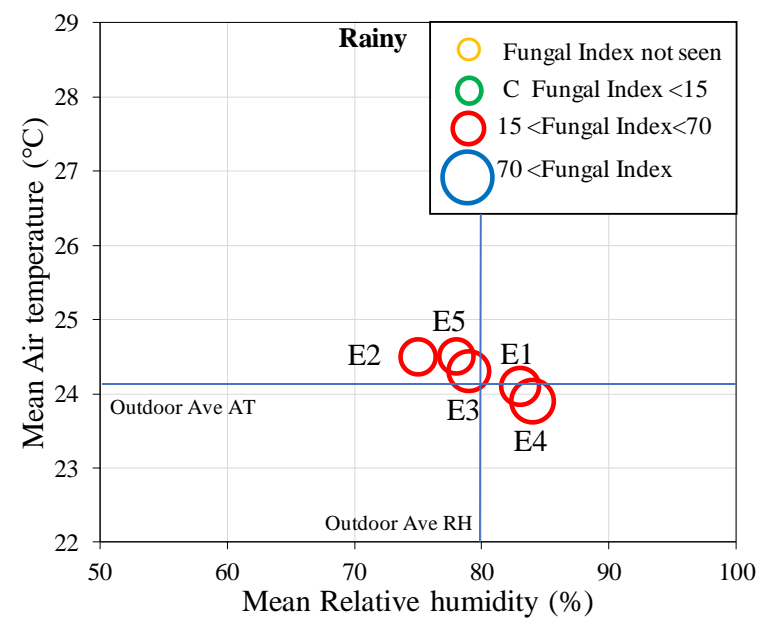

Fig. 24. Mold Results Related to AT \& RH in Unit 5 (Rainy Season) 
Behavioral changes such as cleaning the rooms and reducing

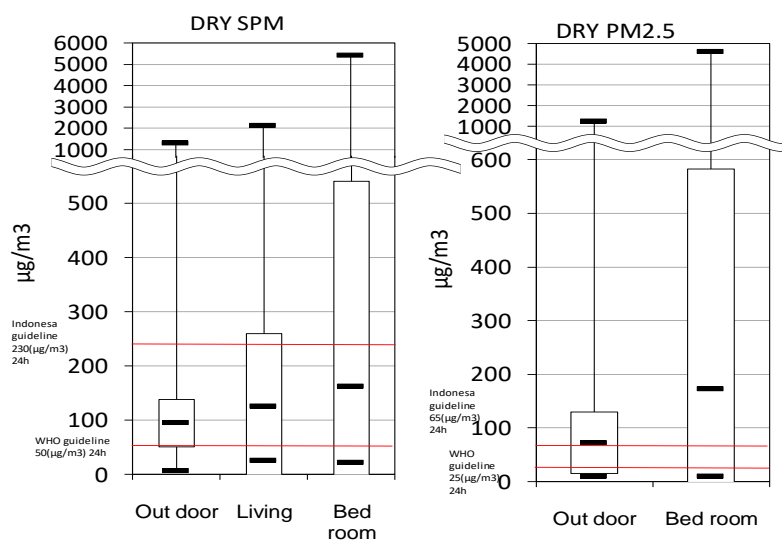

Fig. 25. Dust Measurement Results in Unit 5 (Dry Season)

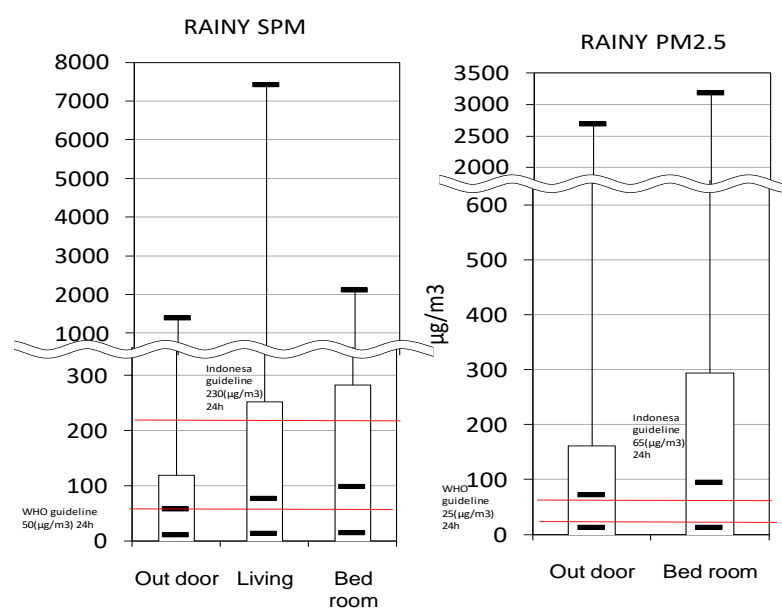

Fig. 26. Dust Measurement Results in Unit 5 (Rainy Season)

\section{CONCLUSIONS}

Key findings from the detailed measurements of the selected five houses are as follows:

1. Most houses are not equipped with sufficient openings/windows, and even if there are windows, the duration of opening windows is found to be short. This causes a severe lack of natural ventilation in most houses. Ultimately, this also results in the dampness, and thus high $\mathrm{RH}$, causing mold growth. The lack of ventilation will also lead to an increase in dust levels, and higher or more frequent TVOC/formaldehyde peaks.

2. Exhaust fans or even simple electric fans are rarely installed in Kampong houses. This results in the lack of ventilation on the other hand.

3. In some cases, IAQ was found to be better than Outdoor Air Quality (OAQ). In that case, opening windows will result in an increase in indoor air pollutions.

Several recommendations were made for each of the five houses, but general means would be (1) installation of more openings/windows with sufficient opening time to improve cross-ventilation, (2) providing additional mechanical ventilators/exhaust fans to release air pollutions, and (3) improvement of roof construction to avoid rain leaking. smoking indoors are also recommended.

\section{ACKNOWLEDGMENT}

This research is supported by a grant from Sumitomo Foundation.

\section{REFERENCES}

[1] World Health Organization, "World Hearth Statistics 2015," WHO Press. Geneva, pp. 62.

[2] J. Sumi, K. B. Adinugraha, T. Kubota, U. Surahman, “インドネシア のカンポン住宅における空気質と健康に関する実態調查, ” AIJ Journal 2019.

[3] World Health Organization, "WHO Air Quality Guidelines for Particulate Matter, Ozone, Nitrogen dioxide and Sulfur dioxide Global update 2005," https://www.env.go.jp/air/tech/ine/asia/indonesia/files/pollution/files/ pollution2016.pdf

[4] Asian Development Bank, "Country Synthesis Report on Urban Air Quality Management Discussion Draft December 2006," Asian Development Bank, 2006, pp. 21. 